\title{
Intergranular Corrosion of Low Cr Ferritic Stainless Steel 429 Evaluated by the Optimized Double Loop Electrochemical Potentiokinetic Reactivation Test
}

\author{
Xiao-lei $\mathrm{Li}^{1}{ }^{1}$ Yi-fan $\mathrm{Ni}^{2}{ }^{2}$ Yi-ming Jiang, ${ }^{2} \mathrm{Jin} \mathrm{Li}^{2}{ }^{2}$ and $\mathrm{Li} \mathrm{Li}^{1}$ \\ ${ }^{1}$ The Center of Analysis and Measurement, Fudan University, Shanghai 200433, China \\ ${ }^{2}$ Department of Materials Science, Fudan University, Shanghai 200433, China \\ Correspondence should be addressed to Yi-ming Jiang; corrosion@fudan.edu.cn
}

Received 30 December 2014; Revised 2 March 2015; Accepted 2 March 2015

Academic Editor: Abbas S. Milani

Copyright (C) 2015 Xiao-lei Li et al. This is an open access article distributed under the Creative Commons Attribution License, which permits unrestricted use, distribution, and reproduction in any medium, provided the original work is properly cited.

\begin{abstract}
Intergranular corrosion (IGC) of $\mathrm{Nb}$-Ti stabilized ferritic stainless steel (FSS) 429 was investigated using the double loop electrochemical potentiokinetic reactivation (DL-EPR) test combined with the microstructure observation. The results indicated that the optimized DL-EPR test condition for FSS 429 was the solution of $0.5 \mathrm{M} \mathrm{H}_{2} \mathrm{SO}_{4}+0.0001 \mathrm{M} \mathrm{KSCN}$ with a scanning rate of $100 \mathrm{mV} / \mathrm{min}$ at $30^{\circ} \mathrm{C}$. Based on this condition, the specimens aging at $400-700^{\circ} \mathrm{C}$ for different duration were tested and a timetemperature-sensitization (TTS) curve for FSS 429 was obtained, which reveals the sensitization nose was located around $550^{\circ} \mathrm{C}$. The critical $I_{r} / I_{a}$ value was determined to be about 3\% above which IGC occurred. After aging treatment, Cr depletion zone was detected using energy dispersive spectroscopy (EDS), most possibly due to Cr segregation around intergranular TiC and $\mathrm{NbC}$.
\end{abstract}

\section{Introduction}

Ferritic stainless steels (FSS) had been widely used in many elevated temperature applications (automotive exhaust systems, steam generators of power plants, and so on) due to its superior resistance to pitting corrosion, good machinability, and high thermal conductivity, as compared with conventional austenitic stainless steels [1-5]. During application, they were inevitably exposed to the temperature range above recrystallization temperature; the thermal cycles would lead to the grain growth and sensitization, causing the intergranular corrosion (IGC) followed by the failure of the appliances [6].

According to the previous researches [7-13], IGC was mainly caused by the Cr depletion around the grain boundaries. During the welding or heat treatment process, $\mathrm{Cr}$ compounds such as $\mathrm{Cr}$-carbides and $\mathrm{Cr}$-nitrides precipitated at the grain boundaries, the Cr-depleted zone adjacent to the intergranular precipitates became the initiation sites, and then IGC was fully developed by the electrochemical potential difference between the Cr-depleted zone and matrix.
To prevent the precipitation of $\mathrm{Cr}$ compounds at the grain boundary, Bond and Lizlovs [7] proposed that the content of carbon and nitrogen should be lower than $0.01 \mathrm{wt} \%$ in $17 \mathrm{wt} \%$ Cr FSS. Various stabilizers such as $\mathrm{Ti}$ and $\mathrm{Nb}$ were added to react preferentially with carbon and nitrogen rather than $\mathrm{Cr}$ [14]. Even if the contents of $\mathrm{C}$ and $\mathrm{N}$ and stabilizers in FSS meet the requirements mentioned above, failures due to the IGC still occurred in low Cr FSS materials during durability testing or actual application. Kim et al. suggested that the Crdepleted region was caused by the segregation of $\mathrm{Cr}$ around intergranular TiC in stabilized FSS 409L [15-19]. However, researches on the IGC of low $\mathrm{Cr}(\sim 14 \mathrm{wt} \%)$ ferritic stainless steels were extremely lacking, especially for FSS 429.

In order to quantitatively detect the effect of fine precipitation and its consequence on the degree of sensitization (DOS) to IGC of stainless steels, Akashi et al. [20] developed a double loop electrochemical potentiokinetic reactivation (DL-EPR) method, which could be used to detect the DOS to IGC of stainless steels fast, nondestructively and quantitatively. To evaluate the DOS to IGC with DL-EPR test, a specific test condition (electrolyte composition, operating 
TABLE 1: Chemical composition of FSS 429 (wt.\%).

\begin{tabular}{lcccccccccccc}
\hline Element & $\mathrm{C}$ & $\mathrm{Si}$ & $\mathrm{Mn}$ & $\mathrm{S}$ & $\mathrm{P}$ & $\mathrm{Cr}$ & $\mathrm{Ni}$ & $\mathrm{Cu}$ & $\mathrm{Nb}$ & $\mathrm{Ti}$ & $\mathrm{N}$ \\
\hline wt.\% & 0.017 & 0.83 & 0.98 & 0.001 & 0.021 & 14.20 & 0.34 & 0.03 & 0.32 & 0.12 & 0.0048 \\
\hline
\end{tabular}

temperature, potential limit, and scanning rate) was essential for each alloy. In previous studies, Hong et al. used the DLEPR test in the solution of $2 \mathrm{M} \mathrm{H}_{2} \mathrm{SO}_{4}+1.5 \mathrm{M} \mathrm{HCl}$ at $30^{\circ} \mathrm{C}$ and with a scanning rate of $1.5 \mathrm{mV} / \mathrm{s}$ to evaluate the DOS to IGC of UNS S32750 duplex stainless steel [21]. Li et al. used the DLEPR test in the solution of $0.5 \mathrm{M} \mathrm{H}_{2} \mathrm{SO}_{4}+0.005 \mathrm{M} \mathrm{Na}_{2} \mathrm{~S}_{4} \mathrm{O}_{6}$ at $40^{\circ} \mathrm{C}$ and with a scanning rate of $1.667 \mathrm{mV} / \mathrm{s}$ to evaluate the DOS to IGC of 316L austenitic stainless steel [12]. Gong et al. used the DL-EPR test in the solution of $2 \mathrm{M} \mathrm{H}_{2} \mathrm{SO}_{4}+1 \mathrm{M} \mathrm{HCl}$ at $30^{\circ} \mathrm{C}$ and with a scanning rate of $1.66 \mathrm{mV} / \mathrm{s}$ to evaluate the DOS to IGC of UNS S31803 duplex stainless steel [22].

In this paper, the DOS to IGC of type 429 , which contains the interstitials of 0.017 wt. $\% \mathrm{C}$ and 0.0048 wt.\% $\mathrm{N}$ and the stabilizers of 0.12 wt. $\% \mathrm{Ti}$ and $0.32 \mathrm{wt} . \% \mathrm{Nb}$, was investigated using DL-EPR test. The first objective of the present study was to determine the optimum conditions (including the electrolyte concentration, scan rate, and temperature) leading to a quantitative evaluation of the IGC susceptibility of type FSS 429 using the DL-EPR test; then the specimens with different heat treatment were tested in order to plot the timetemperature-sensitization (TTS) curve of type FSS 429. In our work, a generic control variate method was used to evaluate the DOS of IGC.

\section{Experimental Procedures}

2.1. Material and Heat Treatments. The material studied in present work was low $\mathrm{Cr}$ ferritic stainless steel 429 . The specimens were machined into a form of $10 \times 10 \times 2 \mathrm{~mm}$ and the chemical composition was listed in Table 1 . The specimens were solution-treated at $1200^{\circ} \mathrm{C}$ for $1 \mathrm{~h}$ (water quenched) and then aged at $400-700^{\circ} \mathrm{C}$ for $15 \mathrm{~min}-8 \mathrm{~h}$ (water quenched). All the heat treatments were operated in the atmosphere of $\mathrm{N}_{2}$.

2.2. Method and Criteria of DL-EPR Test. The DL-EPR tests were conducted by using a potentiostat workstation CHI 660D comprised of three electrodes. A graphite rod and a saturated calomel electrode (SCE) were used as the counter and reference electrodes, respectively. The working electrode was constructed using the FSS samples embedded in epoxy resin with an exposure area of $1 \mathrm{~cm}^{2}$. Prior to each experiment, the specimens were successively grounded to 2000 grit using series of sandpaper, then cleaned with alcohol, and dried in hot air.

During the DL-EPR test, the working electrode was firstly cathodically polarized at $900 \mathrm{mV}$ versus SCE for $2 \mathrm{~min}$ to improve reproducibility. Secondly, nearly steady-state open circuit potential $\left(E_{\text {ocp}}\right)$ was reached (about $5 \mathrm{~min}$ ). Thirdly, the potential was scanned from the open circuit corrosion potential to $+600 \mathrm{mV}$ (SCE) and then back to the initial corrosion potential. During the anodic scan, the specimen was anodically polarized from an active state to a passive state.
TABLE 2: Design of experiments for the optimization of DL-EPR test conditions.

\begin{tabular}{lccc}
\hline $\mathrm{H}_{2} \mathrm{SO}_{4}\left(\mathrm{~mol} \cdot \mathrm{L}^{-1}\right)$ & $\mathrm{KSCN}\left(\mathrm{mol} \cdot \mathrm{L}^{-1}\right)$ & $T\left({ }^{\circ} \mathrm{C}\right)$ & $d E / d t(\mathrm{mV} / \mathrm{min})$ \\
\hline 0.1 & 0 & 30 & 100 \\
0.5 & 0 & 30 & 100 \\
1.0 & 0 & 30 & 100 \\
1.5 & 0 & 30 & 100 \\
0.5 & 0.01 & 30 & 100 \\
0.5 & 0.001 & 30 & 100 \\
0.5 & 0.0001 & 30 & 100 \\
0.5 & 0.0001 & 20 & 100 \\
0.5 & 0.0001 & 40 & 100 \\
0.5 & 0.0001 & 30 & 30 \\
0.5 & 0.0001 & 30 & 60 \\
0.5 & 0.0001 & 30 & 150 \\
0.5 & 0.0001 & 30 & 300 \\
\hline
\end{tabular}

In this process, the dissolution occurred and the passive film formed then. During the reverse scan, the passive film around the Cr-depleted region breaks while that on the matrix kept integrity. The current in the anodic and reverse scan was measured separately and the DOS to IGC was evaluated by $R_{a}$ (the ratio of the reactivation $\left(I_{r}\right)$ and anodic $\left(I_{a}\right)$ current density) [23]. For each specimen, at least three-time measurements were carried out.

Due to the great difference in chemical composition and precipitation kinetics of test materials, $R_{a}$ value was strongly dependent on the nature of the electrolyte and the test conditions, so it was very necessary to determine the optimal operation conditions for FSS 429 in the first place. According to the previous studies [20-23], an experimental design involving the change of the main factors controlling the DL-EPR test response was established as shown in Table 2. The operating conditions listed in Table 2 were discussed separately and the optimized condition was reached in the discussion section.

2.3. Microstructural Characterization. After the DL-EPR measurement, the morphologies were observed by light optical microscopy (LOM) and scanning electronic microscopy (SEM Phillips XL30 FEG) with electron dispersive X-ray spectroscopy (EDS).

\section{Results and Discussion}

\subsection{Optimization of DL-EPR Test Conditions}

3.1.1. Influence of Sulfuric Acid Concentration. The DL-EPR tests were conducted in different concentration of $\mathrm{H}_{2} \mathrm{SO}_{4}$ with a scanning rate of $100 \mathrm{mV} / \mathrm{min}$ at $30^{\circ} \mathrm{C}$. The results 


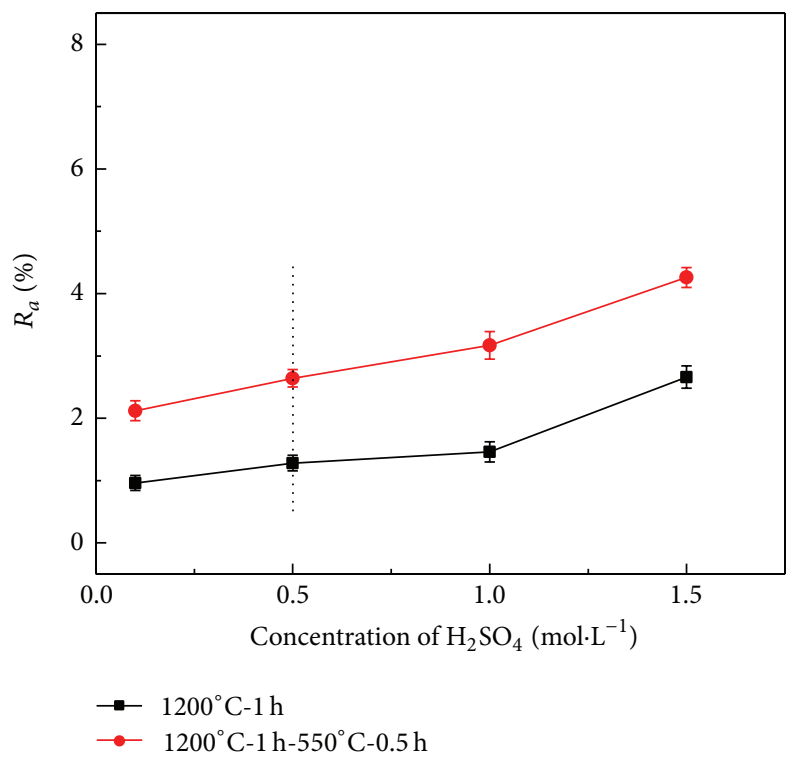

(a)

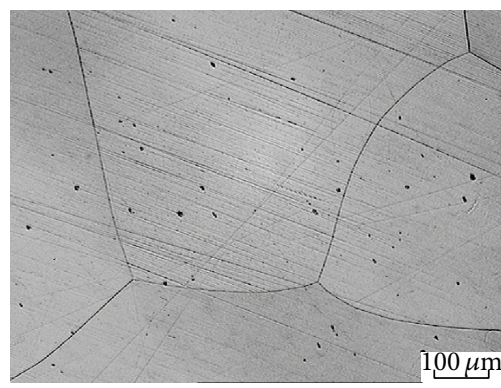

(b)

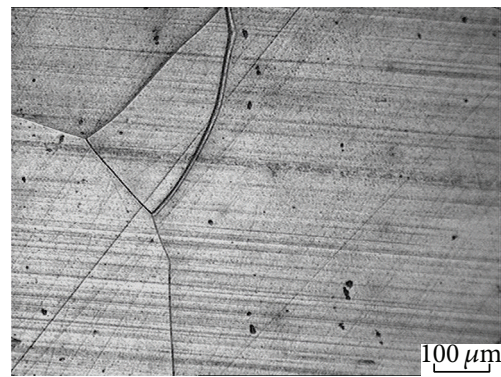

(d)

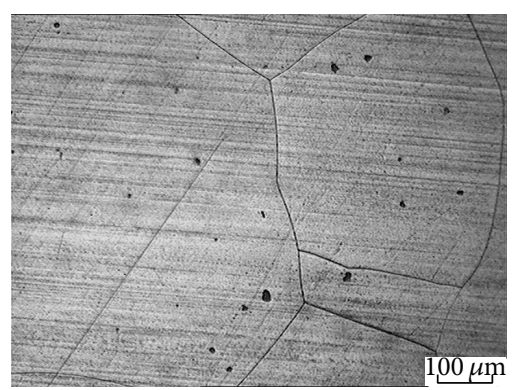

(c)

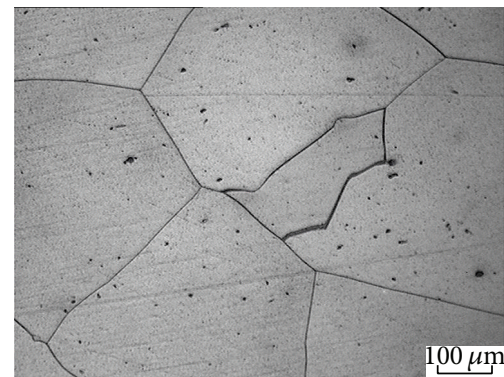

(e)

FIgURE 1: Effect of $\mathrm{H}_{2} \mathrm{SO}_{4}$ concentration in the DL-EPR test. (a) Influence on $R_{a}$ values $\left(d E / d t=100 \mathrm{mV} / \mathrm{min}\right.$ and $\left.T=30^{\circ} \mathrm{C}\right)$; (b)-(e) micrographs of FSS 429 aging at $550^{\circ} \mathrm{C}$ for $1 \mathrm{~h}$ after test, (b) $0.1 \mathrm{M} \mathrm{H}_{2} \mathrm{SO}_{4}$, (c) $0.5 \mathrm{M} \mathrm{H}_{2} \mathrm{SO}_{4}$, (d) $1.0 \mathrm{M} \mathrm{H}_{2} \mathrm{SO}_{4}$, and (e) $1.5 \mathrm{M} \mathrm{H}_{2} \mathrm{SO}_{4}$.

concerning the optimization of the scan rate and the solution temperature were discussed in detail below. The $R_{a}$ values increased with increasing $\mathrm{H}_{2} \mathrm{SO}_{4}$ concentration for the aged specimens as well as the solution-treated specimens, as shown in Figure 1(a). The morphologies of aged specimens presented the evidence of IGC after DL-EPR test in the solution of $0.1-1.5 \mathrm{M} \mathrm{H}_{2} \mathrm{SO}_{4}$ as shown in Figures $1(\mathrm{~b})-1(\mathrm{~d})$. Therefore, it could be implied that higher $\mathrm{H}_{2} \mathrm{SO}_{4}$ concentrations do not substantially modify the $R_{a}$ ratio, but they do weaken the DL-EPR test selectivity by favoring the presence of general corrosion. To maintain low $R_{a}$ values of the solutiontreated specimens, $0.5 \mathrm{M}$ was recommended as the optimum concentration of $\mathrm{H}_{2} \mathrm{SO}_{4}$. In order to satisfy good selectivity, an addition of depassivator was necessary for DL-EPR test.

3.1.2. Influence of Depassivator Concentration. The electrolyte consisted of $0.5 \mathrm{M} \mathrm{H}_{2} \mathrm{SO}_{4}$ with a controlled addition of $\mathrm{KSCN}$ $(0.0001,0.001$, and $0.01 \mathrm{M})$ as a depassivator agent. The specified concentration of $\mathrm{KSCN}$ was $0.0001 \mathrm{M}$, corresponding to tests carried out at $30^{\circ} \mathrm{C}$ with scan rate of $100 \mathrm{mV} / \mathrm{min}$. 


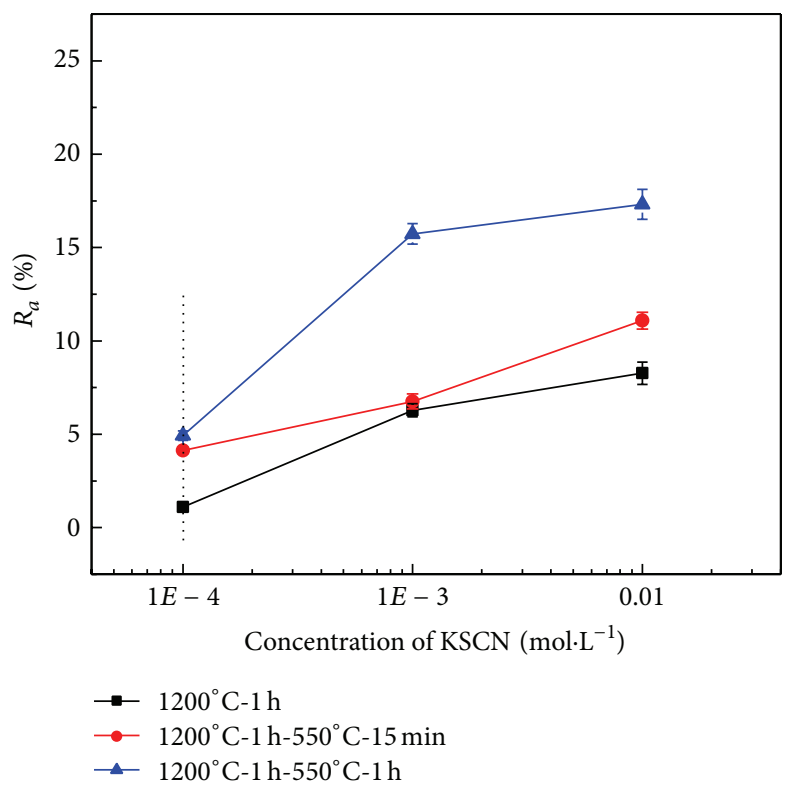

(a)

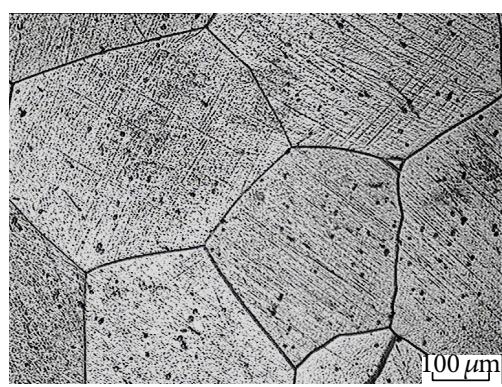

(b)

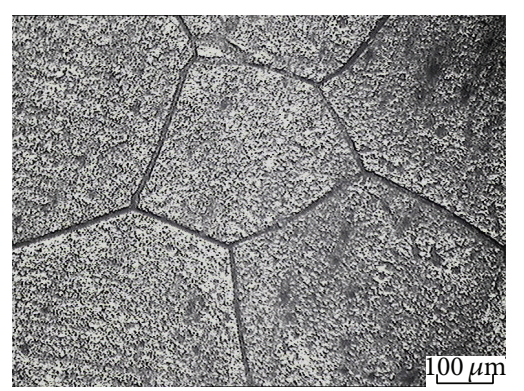

(c)

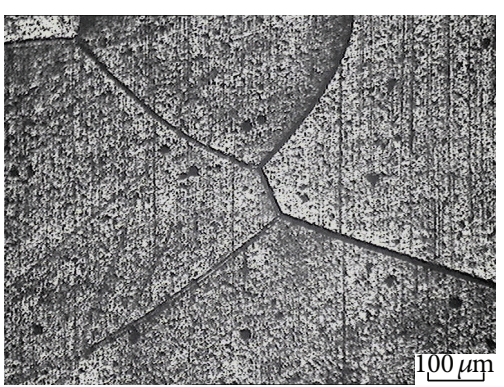

(d)

Figure 2: Effect of KSCN concentration in the DL-EPR test. (a) Influence on $R_{a}$ values $\left(d E / d t=100 \mathrm{mV} / \mathrm{min}\right.$ and $\left.T=30^{\circ} \mathrm{C}\right)$; (b)-(d) micrographs of FSS 429 aging at $550^{\circ} \mathrm{C}$ for 15 min after test, (b) $0.0001 \mathrm{M} \mathrm{KSCN}$, (c) $0.001 \mathrm{M} \mathrm{KSCN}$, and (d) $0.01 \mathrm{M} \mathrm{KSCN}$.

Figure 2 showed the $R_{a}$ values and the microstructure of specimens after test, of all three types of specimens; the DOS increased with increasing KSCN concentration. The distinction of $R_{a}$ values was much more significant when the concentration of KSCN was higher than $0.001 \mathrm{M}$. However, for KSCN above $0.001 \mathrm{M}$, the degree of sensitization was higher than $5 \%$ for the solution-treated specimen, and the microstructure of that indicated the occurrence of general corrosion. The specimens aged at $550^{\circ} \mathrm{C}$ for $15 \mathrm{~min}$ promoted severe sensitization after DL-EPR tests as shown in Figures 2(c) and 2(d), which implied that the concentration of KSCN has a positive effect during the procedure of IGC. Only when the concentration of KSCN was located at $0.0001 \mathrm{M}$, the nonsensitized specimens (solution-treated) retained the value of $I_{r} / I_{a}<2 \%$ and the sensitized specimens (aged for $15 \mathrm{~min}$ ) presented a $R_{a}$ value equal to $5 \%$. Thus, it can be concluded that setting the concentration of KSCN as $0.0001 \mathrm{M}$ was a fine balance between sufficiently aggressive attack and good selectivity.
3.1.3. Influence of Electrolyte Temperature. In order to study the effect of electrolyte temperature on the measurement of DOS, the DL-EPR tests were carried out at different temperatures from 20 to $40^{\circ} \mathrm{C}$ under the fixed conditions of the electrolyte concentration $\left(0.5 \mathrm{M} \mathrm{H}_{2} \mathrm{SO}_{4}+0.0001 \mathrm{M}\right.$ $\mathrm{KSCN})$ and scan rate $(100 \mathrm{mV} / \mathrm{min})$, as shown in Figure 3. The $R_{a}$ value changed significantly with the increase of temperature for the aged specimen. When the temperature was $20^{\circ} \mathrm{C}$, the DOS of sensitized specimen (aged for $15 \mathrm{~min}$ ) was less than $2 \%$, implying the insufficient acquisition of reactivation currents during the reactivation scan. When the temperature was higher than $30^{\circ} \mathrm{C}$, the solution became excessively aggressive for the specimens and caused the total dissolution of the $15 \mathrm{~min}$ aged specimen as shown in Figure 3(d). Accordingly, $30^{\circ} \mathrm{C}$ was recommended as the optimum solution temperature.

3.1.4. Effect of Potential Scanning Rate. The DL-EPR tests in $0.5 \mathrm{M} \mathrm{H}_{2} \mathrm{SO}_{4}$ were conducted at different scanning rates 


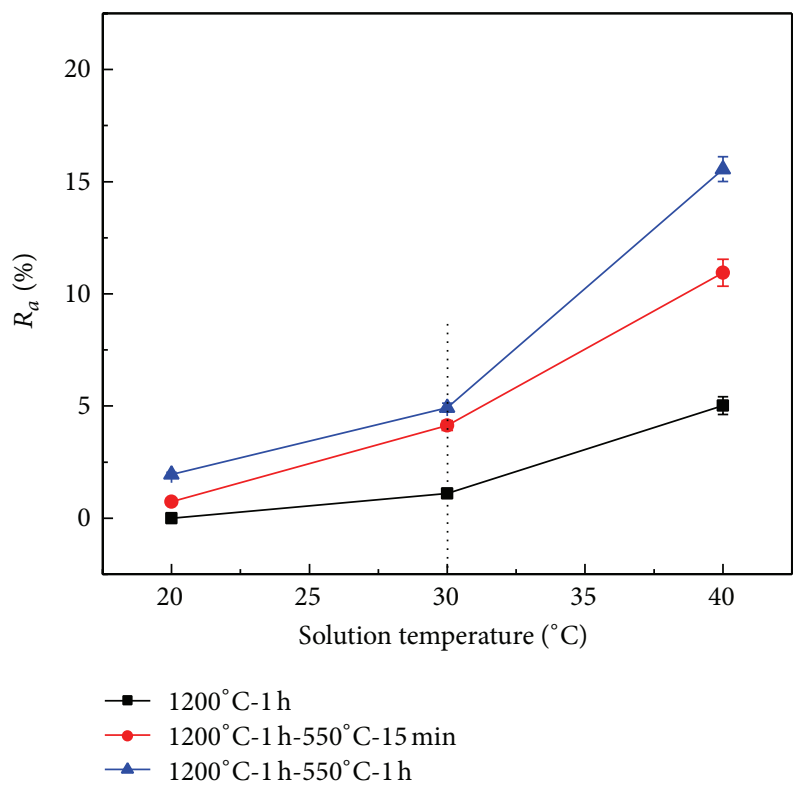

(a)

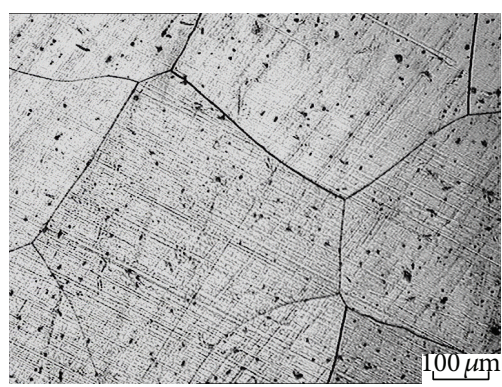

(b)

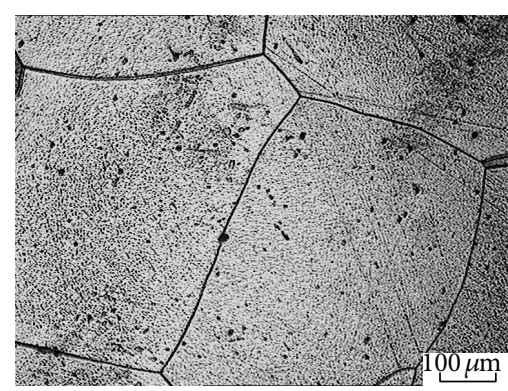

(c)

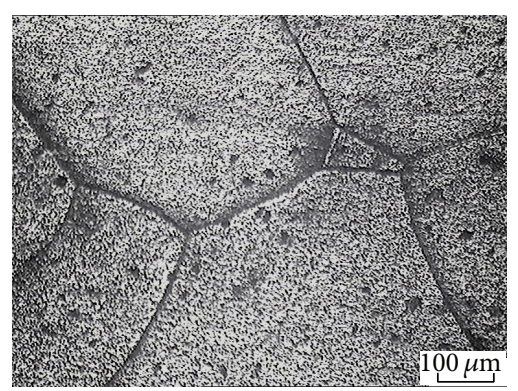

(d)

FIGURE 3: Effect of solution temperature in the DL-EPR test. (a) Influence on $R_{a}$ values $\left(0.5 \mathrm{M} \mathrm{H}_{2} \mathrm{SO}_{4}+0.0001 \mathrm{M} \mathrm{KSCN}, d E / d t=\right.$ $100 \mathrm{mV} / \mathrm{min}$ ); (b)-(d) micrographs of FSS 429 aging at $550^{\circ} \mathrm{C}$ for $15 \mathrm{~min}$ after test, (b) $20^{\circ} \mathrm{C}$, (c) $30^{\circ} \mathrm{C}$, and (d) $40^{\circ} \mathrm{C}$.

of $30,60,100,150$, and $300 \mathrm{mV} / \mathrm{min}$ and under conditions of $0.0001 \mathrm{M} \mathrm{KSCN}$ at a temperature of $30^{\circ} \mathrm{C}$, as shown in Figure 4(a). From the figure, it was obvious that the $R_{a}$ ratio decreased significantly with the increase of scanning rate. The increase of DOS at lower scanning rate was mainly attributed to an increase in the peak current during the reverse scan. When the scan rate was too slow, not only was more passive film on the $\mathrm{Cr}$-depleted region dissolved, but also there was more general corrosion occurring on the entire specimen. On the contrary, at high scan rate, the passive film on the Cr-depleted region could not be dissolved completely, leading to the decrease of the sensitivity of DL-EPR test. The above analysis was confirmed by the micrographs of the specimens after test, Figures 4(b)-4(f). Hence, the scan rate of $100 \mathrm{mV} / \mathrm{min}$ was suitable for an optimal test.

3.2. Effect of Heat Treatment on IGC. To investigate the influence of the heat treatments on the IGC of FSS 429, the specimens aged at $400-700^{\circ} \mathrm{C}$ for various times are tested in the condition modified before $\left(0.5 \mathrm{M} \mathrm{H}_{2} \mathrm{SO}_{4}+0.0001 \mathrm{M}\right.$ $\mathrm{KSCN}$ with a potential scanning rate of $100 \mathrm{mV} / \mathrm{min}$ at $30^{\circ} \mathrm{C}$ ).
3.2.1. Effect of Aging Time on IGC. Figure 5(a) showed the DL-EPR curves obtained for the specimens aged at $550^{\circ} \mathrm{C}$ for different time ranging from $15 \mathrm{~min}$ to $8 \mathrm{~h}$. The relationship between the degree of sensitization and the aging time was exhibited in Figure 5(b). It could be noted that all materials presented a wide passivity range from $0.1 \mathrm{~V}$ to $0.6 \mathrm{~V}$, with anodic current density at the magnitude order of $10^{-4} \mathrm{~A} / \mathrm{cm}^{2}$ [24-26]. The value of $R_{a}$ increased gradually from $4.13 \%$ to $8.09 \%$ for the specimens aged from $15 \mathrm{~min}$ to $2 \mathrm{~h}$ at $550^{\circ} \mathrm{C}$. According to Kim et al., IGC was induced by the Cr depletion zone formation due to $\mathrm{Cr}$ segregation around intergranular TiC in Ti-stabilized type FSS [27]. With the aging time increasing, Ti-stabilized FSS 429 specimens became more prone to IGC because the Cr segregation increased and the degree of $\mathrm{Cr}$ depletion was enhanced. However, it should be noticed that further prolonging the aging time decreased the $R_{a}$ value. Compared the specimen aged for $8 \mathrm{~h}$ with that aged $2 \mathrm{~h}$, the $R_{a}$ values decreased from $8.09 \%$ to $3.68 \%$. This could be explained by the fact that the chromium-depleted zones were healing up themselves due to the diffusion of $\mathrm{Cr}$ from the matrix after being aged for $8 \mathrm{~h}$. Corrosion resistant alloys 


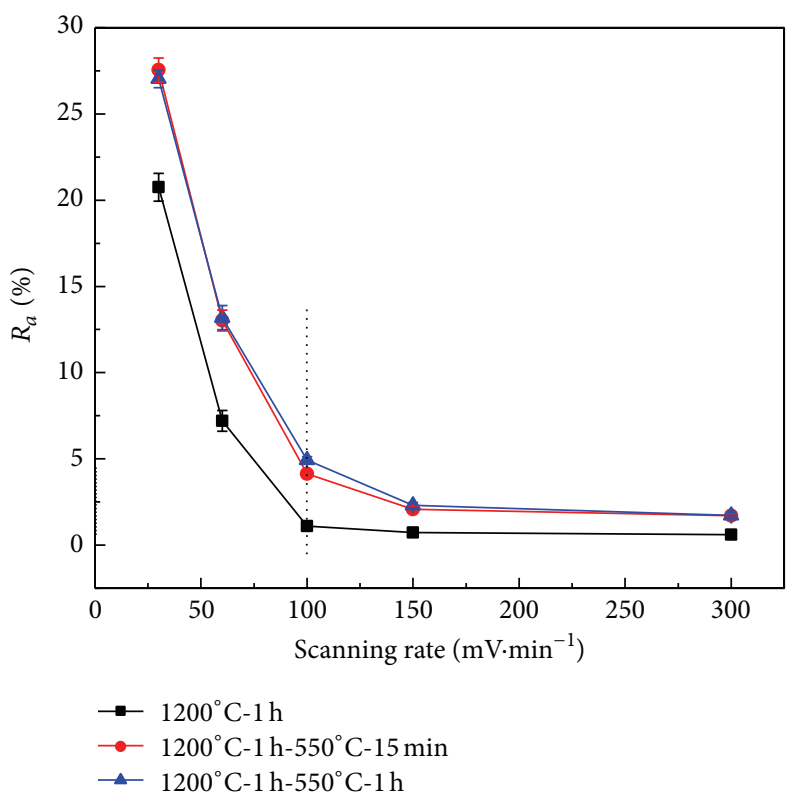

(a)

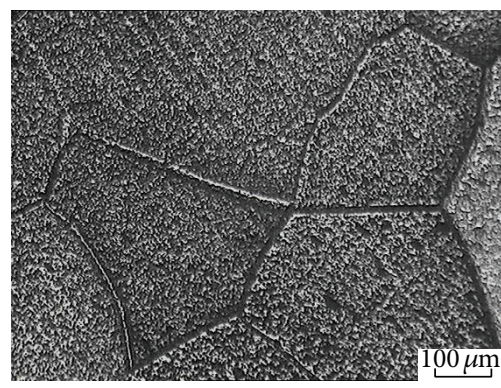

(b)

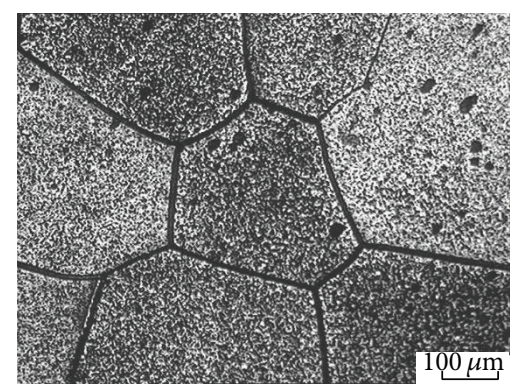

(c)

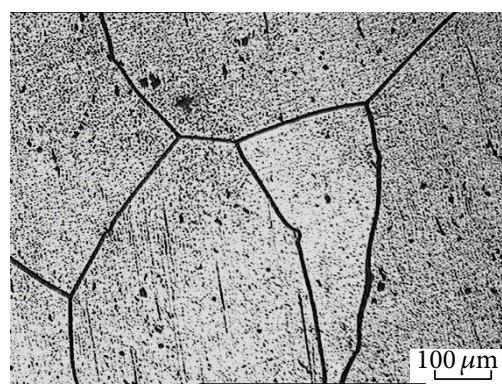

(d)

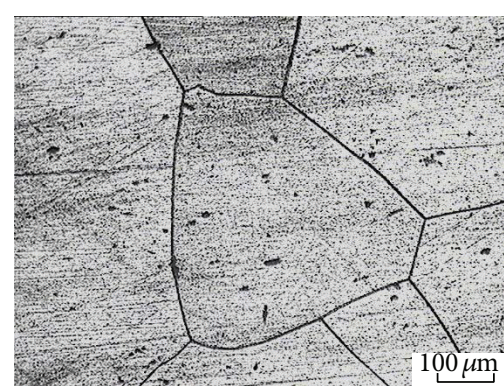

(e)

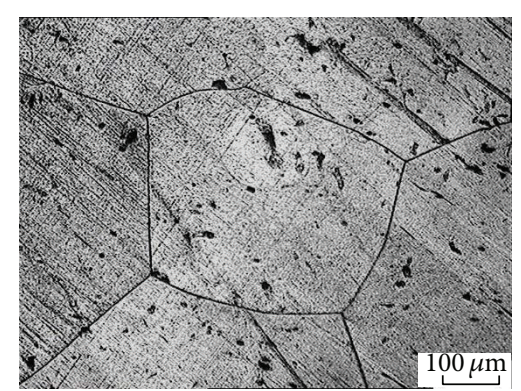

(f)

FIGURE 4: Effect of potential scanning rate in the DL-EPR test. (a) Influence on $R_{a}$ values $\left(0.5 \mathrm{M} \mathrm{H}_{2} \mathrm{SO}_{4}+0.0001 \mathrm{M} \mathrm{KSCN}, T=30^{\circ} \mathrm{C}\right)$; (b)-(f) micrographs of FSS 429 aging at $550^{\circ} \mathrm{C}$ for $1 \mathrm{~h}$ after test, (b) $30 \mathrm{mV} / \mathrm{min}$, (c) $60 \mathrm{mV} / \mathrm{min}$, (d) $100 \mathrm{mV} / \mathrm{min}$, (e) $150 \mathrm{mV} / \mathrm{min}$, and (f) $300 \mathrm{mV} / \mathrm{min}$.

such as stainless steel were capable of a process called healing [28] where Cr diffused into the depleted zones, raising the $\mathrm{Cr}$ level and curing the sensitized region. In this case, $\mathrm{Cr}$ in the intergranular precipitates would diffuse to the grain boundary for specimens aged for as long as $8 \mathrm{~h}$ and restore the chromium depleted region leading to the reduction of the sensitization to the IGC.

Figure 6 compared IGC morphologies of the specimens aged at $550^{\circ} \mathrm{C}$ for various aging times after the DL-EPR tests. As the aging time increased, a deeper attack was evident along the grain boundary, as shown in Figures 6(a)-6(d). As the healing effect appeared, the morphology of the specimen aged for as long as $8 \mathrm{~h}$ became less ravined and the intergranular corrosion had been weakened, as shown in Figure 6(e). In a word, all the surface morphologies were closely related with DL-EPR results.

Figure 7 showed the SEM-EDS characterization at the grain boundary of the solution-treated and aged specimen, in order to further examine the Cr-depletion caused by aging treatment. The $\mathrm{Cr}$ content (12.68 wt.\%) along the grain 


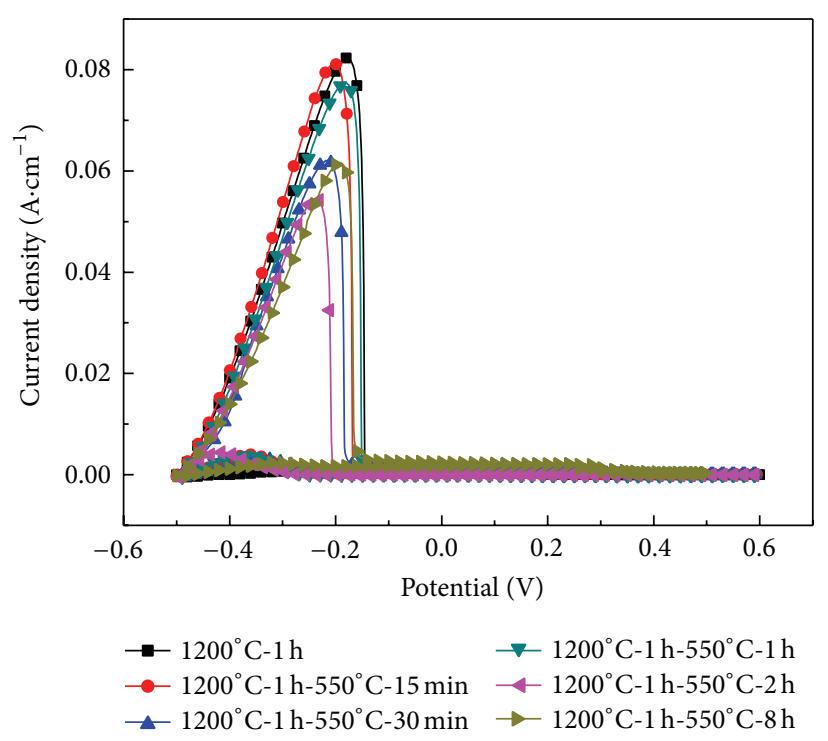

(a)

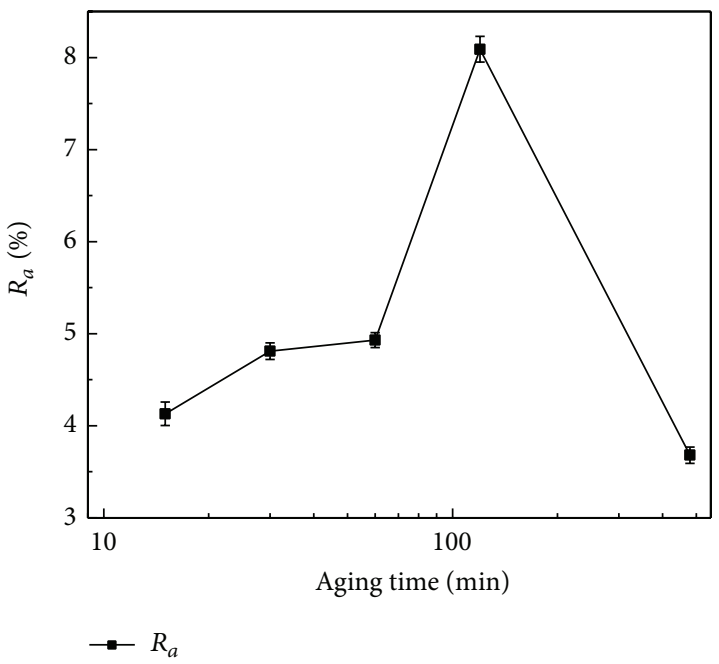

(b)

FIGURE 5: DL-EPR curves and $R_{a}$ values of FSS 429 aging at $550^{\circ} \mathrm{C}$ for different time.

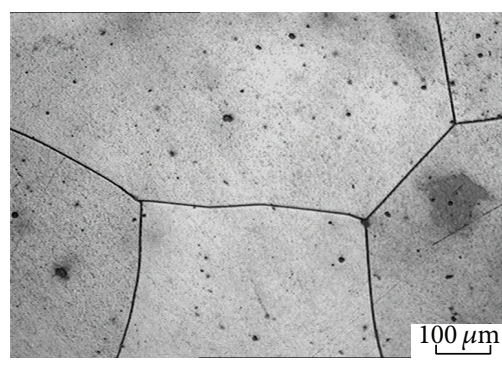

(a)

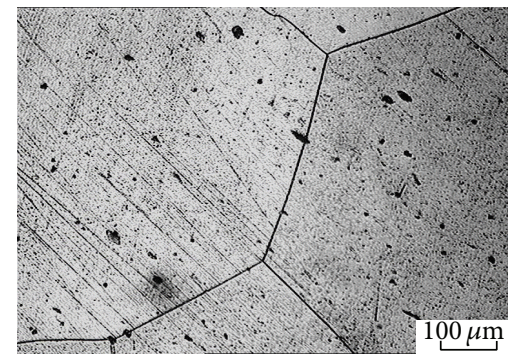

(b)

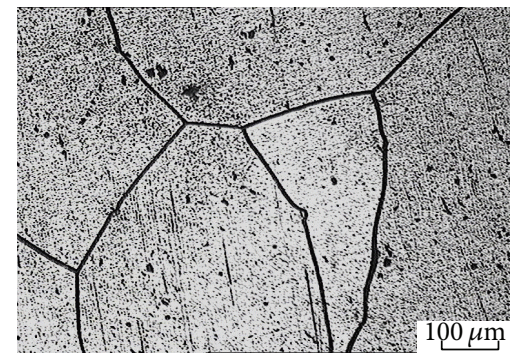

(c)

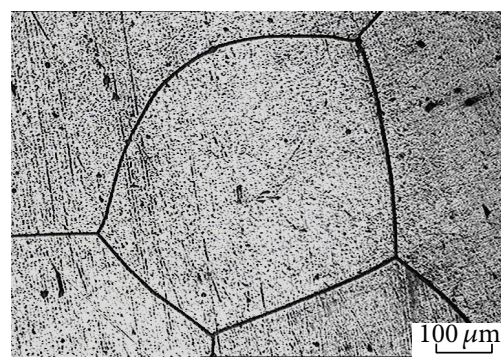

(d)

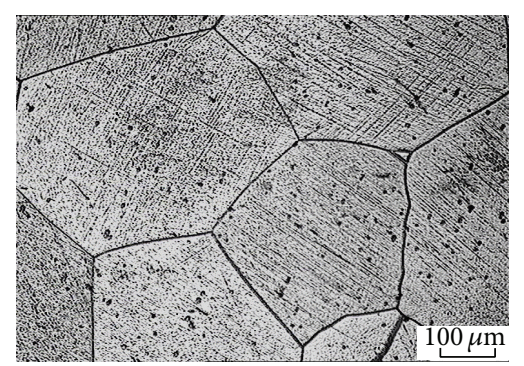

(e)

FIGURE 6: Micrographs of tested FSS 429 aging at $550^{\circ} \mathrm{C}$ for different time: (a) $15 \mathrm{~min}$, (b) $30 \mathrm{~min}$, (c) $1 \mathrm{~h}$, (d) $2 \mathrm{~h}$, and (e) $8 \mathrm{~h}$.

boundary of the specimen aged at $550^{\circ} \mathrm{C}$ for $1 \mathrm{~h}$ was lower than that (14.25 wt.\%) of the solution-treated specimen, which indicated that the $\mathrm{Cr}$-depleted region developed with the increase of aging time. Similar results had been reported by other researchers as well $[15,16,29]$. The previous studies had suggested that $\mathrm{TiC}$ redissolved and soluble $\mathrm{C}$ atoms were produced during the solution treatment at $1200^{\circ} \mathrm{C}$. Suzuki et al. [30] suggested that $\mathrm{Cr}$ had a tendency to segregate at the $\mathrm{TiC}$ interface to relieve supersaturation in matrix at around $500^{\circ} \mathrm{C}$. In this case, $\mathrm{TiC} / \mathrm{NbC}$ reprecipitated along the grain boundary during the aging treatment, and then $\mathrm{Cr}$ segregated around $\mathrm{TiC} / \mathrm{NbC}$ after $\mathrm{TiC} / \mathrm{NbC}$ formation. Consequently, the $\mathrm{Cr}$ segregation developed $\mathrm{Cr}$ depletion zone that caused IGC adjacent to the grain boundary.

3.2.2. Effect of Aging Temperature on IGC. Figure 8 illustrated the DL-EPR curves and the $R_{a}$ values obtained for specimens aging at $400-700^{\circ} \mathrm{C}$ for $1 \mathrm{~h}$. As aging temperature increased from $400^{\circ} \mathrm{C}$ to $550^{\circ} \mathrm{C}$, $\mathrm{Cr}$ segregated around $\mathrm{TiC} / \mathrm{NbC}$ at the grain boundaries and the corresponding sensitization became more obvious. Aging at $550^{\circ} \mathrm{C}$ and $600^{\circ} \mathrm{C}$ for $1 \mathrm{~h}$ produced the biggest degree of sensitization to IGC. While 


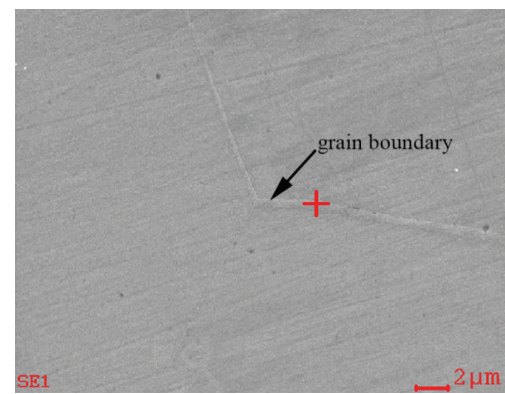

(a)

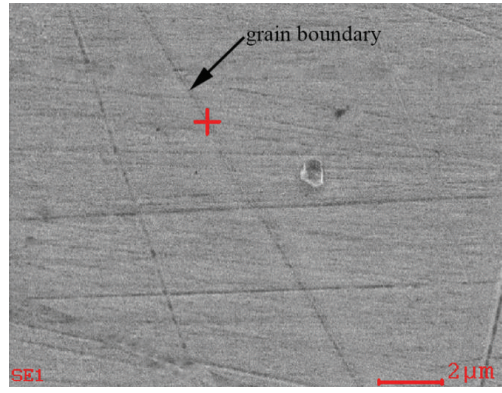

(c)

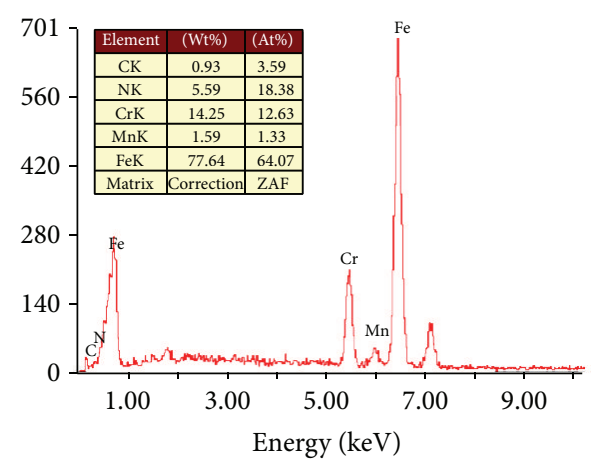

(b)

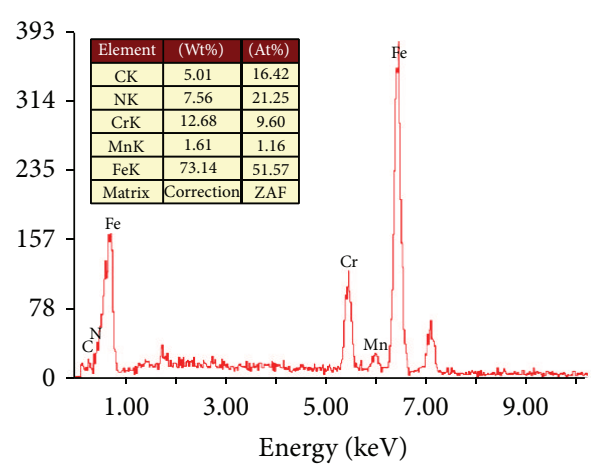

(d)

FIGURE 7: SEM micrographs and EDS analysis results along the grain boundary in FSS 429. (a) Solution specimen, (b) EDS spectra of grain boundary in (a), (c) the specimen aged at $550^{\circ} \mathrm{C}$ for $1 \mathrm{~h}$, and (d) EDS spectra of grain boundary in (d).

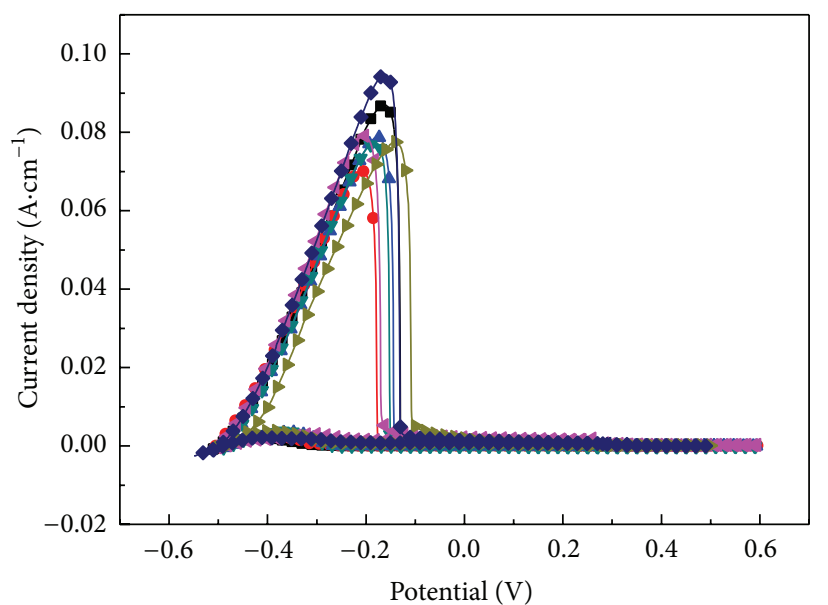

$\rightarrow-1200^{\circ} \mathrm{C}-1 \mathrm{~h}-400^{\circ} \mathrm{C}-1 \mathrm{~h}$ $\rightarrow 1200^{\circ} \mathrm{C}-1 \mathrm{~h}-450^{\circ} \mathrm{C}-1 \mathrm{~h}$

$\leftarrow 1200^{\circ} \mathrm{C}-1 \mathrm{~h}-500^{\circ} \mathrm{C}-1 \mathrm{~h}$

$\rightarrow 1200^{\circ} \mathrm{C}-1 \mathrm{~h}-550^{\circ} \mathrm{C}-1 \mathrm{~h}$

(a)

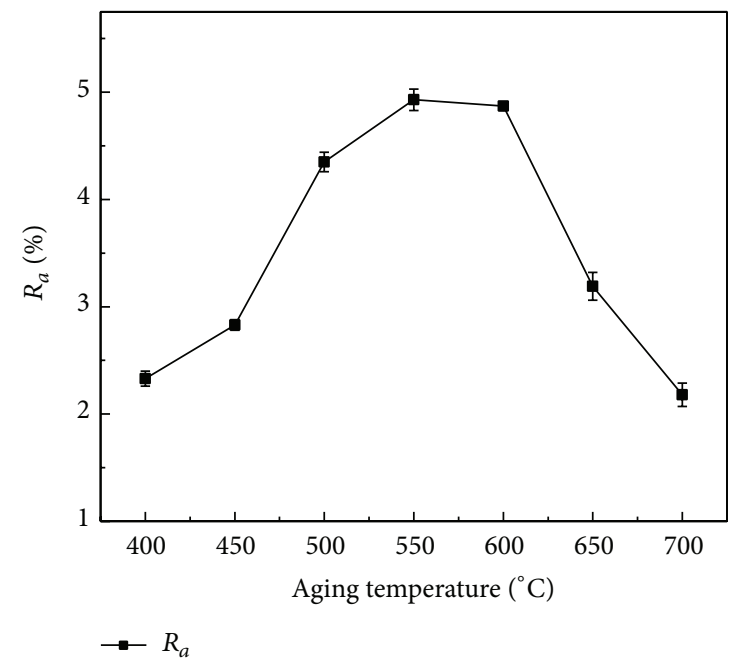

(b)

FIGURE 8: DL-EPR curves and $R_{a}$ values of FSS 429 aging at $400-700^{\circ} \mathrm{C}$ for $1 \mathrm{~h}$. 
TABLE 3: $R_{a}$ values of FSS 429 for different aging treatments.

\begin{tabular}{|c|c|c|c|c|c|}
\hline Aging Temperature $/{ }^{\circ} \mathrm{C}$ & Aging Time/min & $R_{a} / \%$ & Aging Temperature $/{ }^{\circ} \mathrm{C}$ & Aging Time/min & $R_{a} / \%$ \\
\hline 450 & 15 & 1.89 & 600 & 15 & 3.03 \\
\hline 450 & 30 & 2.11 & 600 & 30 & 3.57 \\
\hline 450 & 60 & 2.83 & 600 & 60 & 4.87 \\
\hline 500 & 15 & 1.82 & 600 & 120 & 5.68 \\
\hline 500 & 30 & 2.12 & 650 & 30 & 1.71 \\
\hline 500 & 60 & 4.35 & 650 & 60 & 3.19 \\
\hline 550 & 15 & 4.13 & 650 & 120 & 4.27 \\
\hline 550 & 30 & 4.81 & 700 & 30 & 1.70 \\
\hline 550 & 60 & 4.93 & 700 & 60 & 2.18 \\
\hline 550 & 120 & 8.09 & 700 & 120 & 3.73 \\
\hline 550 & 480 & 3.68 & & & \\
\hline
\end{tabular}

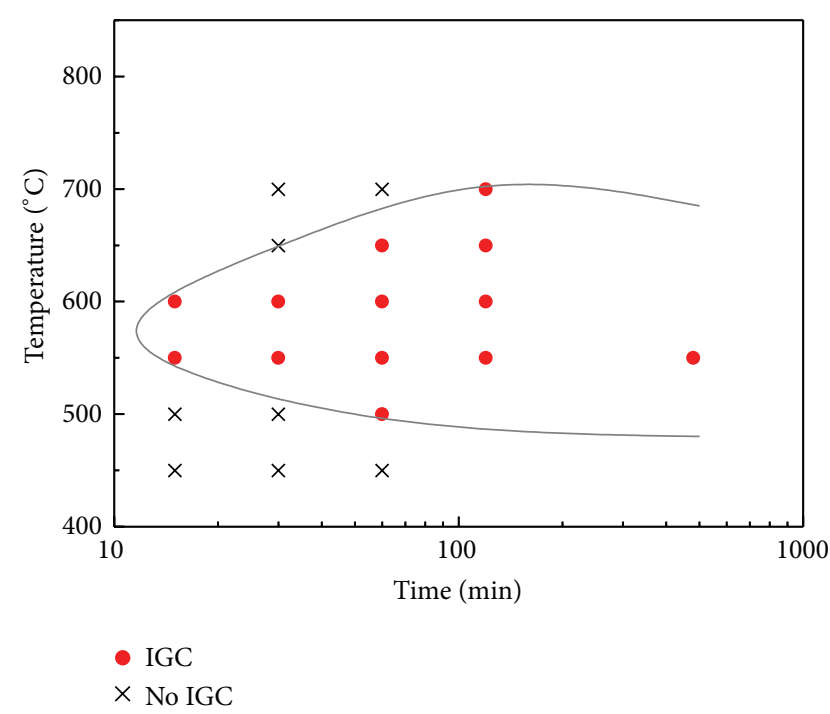

FIgURE 9: Time-temperature-sensitization curve for FSS 429.

the aging temperature continued increasing above $600^{\circ} \mathrm{C}$, the $R_{a}$ value decreased gradually and sensitization was relieved. The measured $R_{a}$ value $(2.18 \%)$ of the specimen aged at $700^{\circ} \mathrm{C}$ for $1 \mathrm{~h}$ was similar to that of solution-treated specimen. This was due to high diffusion rate of chromium at high temperature, and $1 \mathrm{~h}$ was long enough to heal the chromiumdepleted zones at $700^{\circ} \mathrm{C}$. So the nose temperature of FSS 429 located at approximately $550^{\circ} \mathrm{C}$.

\subsection{Time-Temperature-Sensitization (TTS) Curve for FSS 429.}

The TTS curve for FSS 429 was plotted based on $R_{a}$ values (tabulated in Table 3) obtained in the optimized operating conditions and the microstructures after the DL-EPR tests, as shown in Figure 9. The curve showed that the IGC mainly occurred in the specimens aging at the temperature range of $450-600^{\circ} \mathrm{C}$. Beyond this range (like $450^{\circ} \mathrm{C}, 650^{\circ} \mathrm{C}$, and $700^{\circ} \mathrm{C}$ ), the IGC was slight when the aging time was long enough. The sensitization nose was located around $550^{\circ} \mathrm{C}$.

\section{Conclusions}

The Ti-Nb stabilized FSS 429 was investigated using DL-EPR test, LOM, and SEM-EDS. The results of this work suggested the following conclusions.

The optimum DL-EPR condition to evaluate DOS to IGC of FSS 429 was in a $0.5 \mathrm{M} \mathrm{H}_{2} \mathrm{SO}_{4}+0.0001 \mathrm{M} \mathrm{KSCN}$ solution with a potential scanning rate of $100 \mathrm{mV} / \mathrm{min}$ at $30^{\circ} \mathrm{C}$.

The DOS to IGC of FSS 429 obtained by DL-EPR increased with the aging time in the range from $15 \mathrm{~min}$ to $2 \mathrm{~h}$. This could be explained by the $\mathrm{Cr}$ segregation around $\mathrm{TiC} / \mathrm{NbC}$ after the $\mathrm{TiC} / \mathrm{NbC}$ reprecipitation, leading to the development of $\mathrm{Cr}$ depletion zone that caused IGC adjacent to the grain boundary. Further prolonging the aging time decreased the degree of sensitization, which resulted from the healing effect brought by the diffusion of Cr. The DOS to IGC of FSS 429 increased with the aging temperature between 450 and $550^{\circ} \mathrm{C}$ and decreased as the aging temperature increasing above $650^{\circ} \mathrm{C}$. The nose temperature of FSS 429 was around $550^{\circ} \mathrm{C}$.

\section{Conflict of Interests}

The authors declare that there is no conflict of interests regarding the publication of this paper.

\section{Acknowledgments}

The authors would like to thank Hu Gang for his great help with SEM analysis, whilst they gratefully acknowledge the helpful collaboration of Baosteel. This work was supported by the National Natural Science Foundation of China (Grants nos. 51134010, 51131008, and 51371053) and the National Key Technology R\&D Program (2012BAE04B00).

\section{References}

[1] P.-O. Santacreu, O. Cleizergues, C. Simon, and P. Duroux, "Design of stainless steel automotive exhaust manifolds," Revue de Metallurgie. Cahiers D'Informations Techniques, vol. 101, no. 7-8, pp. 615-620, 2004. 
[2] H. Sidhom, T. Amadou, and C. Braham, "Evaluation by the double loop electrochemical potentiokinetic reactivation test of aged ferritic stainless steel intergranular corrosion susceptibility," Metallurgical and Materials Transactions A: Physical Metallurgy and Materials Science, vol. 41, no. 12, pp. 3136-3150, 2010.

[3] V. S. Yarkovoi, "Thermodynamic analysis and intergranular corrosion of corrosion-resistant chrome-manganese steels with nitrogen," Metal Science and Heat Treatment, vol. 35, no. 5, pp. 273-277, 1993.

[4] J. Shu, H. Bi, X. Li, and Z. Xu, "The effect of copper and molybdenum on pitting corrosion and stress corrosion cracking behavior of ultra-pure ferritic stainless steels," Corrosion Science, vol. 57, pp. 89-98, 2012.

[5] M. Akita, M. Nakajima, Y. Uematsu, and K. Tokaji, "Effects of annealing and quenching on fatigue behaviour in type 444 ferritic stainless steel," Fatigue and Fracture of Engineering Materials and Structures, vol. 31, no. 11, pp. 959-966, 2008.

[6] E. Ranjbarnodeh, S. Hanke, S. Weiss, and A. Fischer, "Effect of welding parameters on the heat-affected zone of AISI409 ferritic stainless steel," International Journal of Minerals, Metallurgy and Materials, vol. 19, no. 10, pp. 923-929, 2012.

[7] A. P. Bond and E. A. Lizlovs, "Intergranular corrosion of ferritic stainless steels," Journal of the Electrochemical Society, vol. 116, no. 9, pp. 1305-1311, 1969.

[8] A. P. Bond, "Mechanisms of intergranular corrosion in ferritic stainless steels," Transactions of the Metallurgical Society of AIME, vol. 245, no. 10, pp. 2127-2134, 1969.

[9] R. J. Hodges, "Intergranular corrosion in high purity ferritic stainless steels-effect of cooling rate and alloy composition," Corrosion, vol. 27, no. 3, pp. 119-127, 1971.

[10] C. Stwaström and M. Hillert, "An improved depleted-zone theory of intergranular corrosion of 18-8 stainless steel," Journal of the Iron and Steel Institute, vol. 207, pp. 77-85, 1969.

[11] Y. S. Lim, J. S. Kim, H. P. Kim, and H. D. Cho, "The effect of grain boundary misorientation on the intergranular $\mathrm{M}_{23} \mathrm{C}_{6}$ carbide precipitation in thermally treated Alloy 690," Journal of Nuclear Materials, vol. 335, no. 1, pp. 108-114, 2004.

[12] S.-X. Li, L. Li, S.-R. Yu, R. Akid, and H.-B. Xia, "Investigation of intergranular corrosion of $316 \mathrm{~L}$ stainless steel diffusion bonded joint by electrochemical potentiokinetic reactivation," Corrosion Science, vol. 53, no. 1, pp. 99-104, 2011.

[13] J. S. Armijo, "Intergranular corrosion of nonsensitized austenitic stainless steels," Corrosion, vol. 24, no. 1, p. 24, 1968.

[14] A. Pardo, M. C. Merino, A. E. Coy, F. Viejo, M. Carboneras, and R. Arrabal, "Influence of $\mathrm{Ti}, \mathrm{C}$ and $\mathrm{N}$ concentration on the intergranular corrosion behaviour of AISI 316 Ti and 321 stainless steels," Acta Materialia, vol. 55, no. 7, pp. 2239-2251, 2007.

[15] J. K. Kim, Y. H. Kim, S. H. Uhm, J. S. Lee, and K. Y. Kim, “Intergranular corrosion of Ti-stabilized $11 \mathrm{wt} \% \mathrm{Cr}$ ferritic stainless steel for automotive exhaust systems," Corrosion Science, vol. 51, no. 11, pp. 2716-2723, 2009.

[16] J. K. Kim, Y. H. Kim, B. H. Lee, and K. Y. Kim, "New findings on intergranular corrosion mechanism of stabilized stainless steels," Electrochimica Acta, vol. 56, no. 4, pp. 1701-1710, 2011.

[17] J. K. Kim, Y. H. Kim, and K. Y. Kim, "Influence of Cr, C and Ni on intergranular segregation and precipitation in Ti-stabilized stainless steels," Scripta Materialia, vol. 63, no. 4, pp. 449-451, 2010.

[18] J. H. Park, J. K. Kim, B. H. Lee, H. S. Seo, and K. Y. Kim, "Effect of $\mathrm{Zr}$ addition on intergranular corrosion of low-chromium ferritic stainless steel," Scripta Materialia, vol. 76, pp. 77-80, 2014.

[19] M. P. Phaniraj, D.-I. Kim, and Y. W. Cho, "Effect of grain boundary characteristics on the oxidation behavior of ferritic stainless steel," Corrosion Science, vol. 53, no. 12, pp. 4124-4130, 2011.

[20] M. Akashi, T. Kawamoto, F. Umemura, and B. Gijutsu, "Evaluation of IGSCC susceptibility of austenitic stainless steels using electrochemical reactivation method," Corrosion Engineering, vol. 29, p. 163, 1980.

[21] J. F. Hong, D. Han, H. Tan, J. Li, and Y. Jiang, "Evaluation of aged duplex stainless steel UNS S32750 susceptibility to intergranular corrosion by optimized double loop electrochemical potentiokinetic reactivation method," Corrosion Science, vol. 68, pp. 249-255, 2013.

[22] J. Gong, Y. M. Jiang, B. Deng, J. L. Xu, J. P. Hu, and J. Li, "Evaluation of intergranular corrosion susceptibility of UNS S31803 duplex stainless steel with an optimized double loop electrochemical potentiokinetic reactivation method," Electrochimica Acta, vol. 55, no. 18, pp. 5077-5083, 2010.

[23] J. Gao, Y. M. Jiang, B. Deng, W. Zhang, C. Zhong, and J. Li, "Investigation of selective corrosion resistance of aged lean duplex stainless steel 2101 by non-destructive electrochemical techniques," Electrochimica Acta, vol. 54, no. 24, pp. 5830-5835, 2009.

[24] C. Zhong, F. Liu, Y. T. Wu et al., "Protective diffusion coatings on magnesium alloys: a review of recent developments," Journal of Alloys and Compounds, vol. 520, pp. 11-21, 2012.

[25] C. Zhong, M. He, L. Liu et al., "Lower temperature fabrication of continuous intermetallic coatings on AZ91D magnesium alloy in molten salts," Journal of Alloys and Compounds, vol. 504, no. 2, pp. 377-381, 2010.

[26] J. Le, L. Liu, F. Liu, Y. Deng, C. Zhong, and W. Hu, "Interdiffusion kinetics of the intermetallic coatings on AZ91D magnesium alloy formed in molten salts at lower temperatures," Journal of Alloys and Compounds, vol. 610, pp. 173-179, 2014.

[27] J. K. Kim, B.-J. Lee, B. H. Lee, Y. H. Kim, and K. Y. Kim, "Intergranular segregation of $\mathrm{Cr}$ in Ti-stabilized low-Cr ferritic stainless steel," Scripta Materialia, vol. 61, no. 12, pp. 1133-1136, 2009.

[28] K. Osozawa, K. Bohnenkamp, and H.-J. Engell, "Potentiostatic study on the intergranular corrosion of an austenitic chromium-nickel stainless steel," Corrosion Science, vol. 6, no. 9-10, pp. 421-433, 1966.

[29] J. K. Kim, Y. H. Kim, J. S. Lee, and K. Y. Kim, "Effect of chromium content on intergranular corrosion and precipitation of Ti-stabilized ferritic stainless steels," Corrosion Science, vol. 52, no. 5, pp. 1847-1852, 2010.

[30] M. Suzuki, S. Hamada, P. J. Maziasz, S. Jitsukawa, and A. Hishinuma, "Compositional behavior and stability of MC-type precipitates in JPCA austenitic stainless steel during HFIR irradiation," Journal of Nuclear Materials, vol. 191-194, pp. 13511355, 1992. 

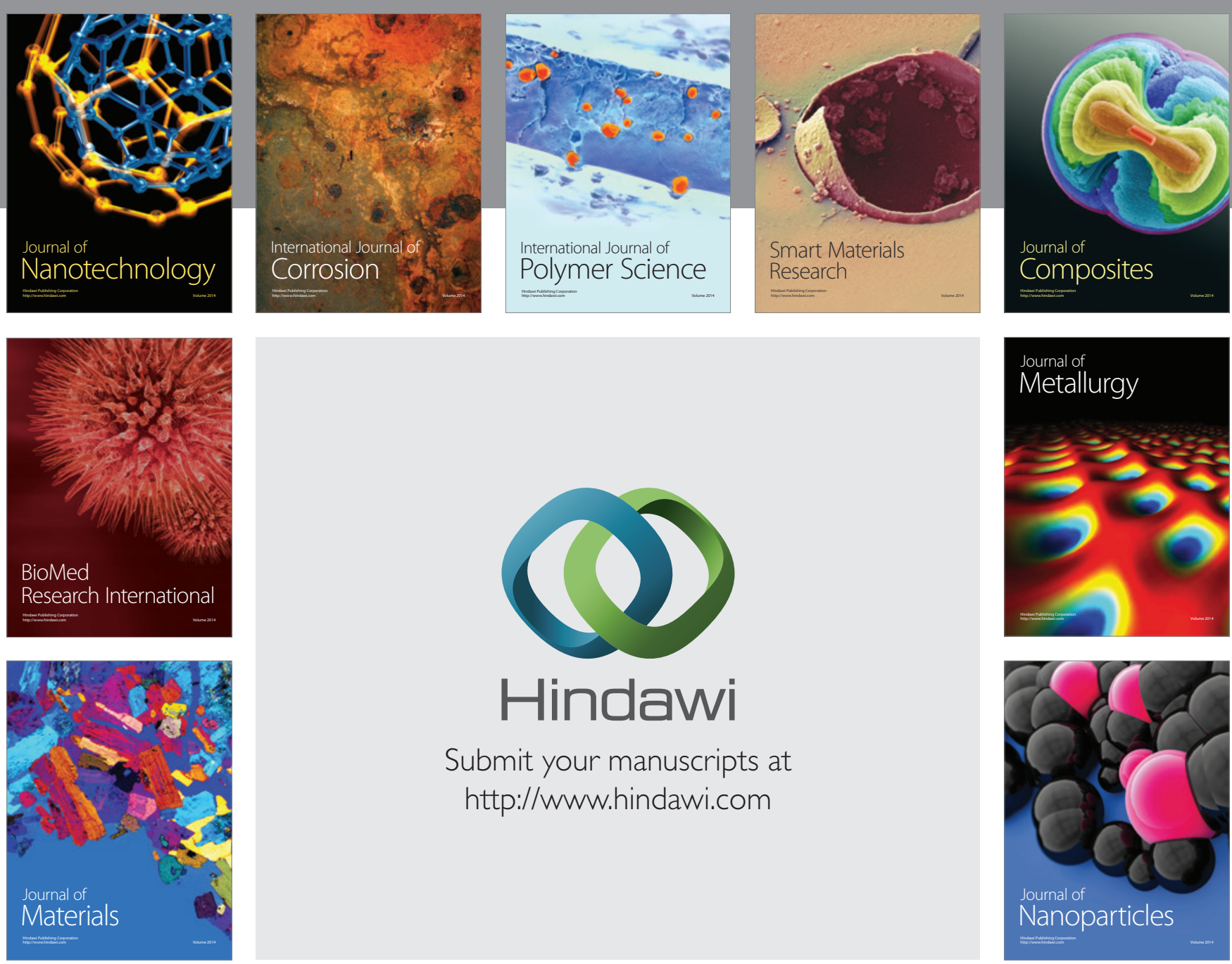

Submit your manuscripts at http://www.hindawi.com
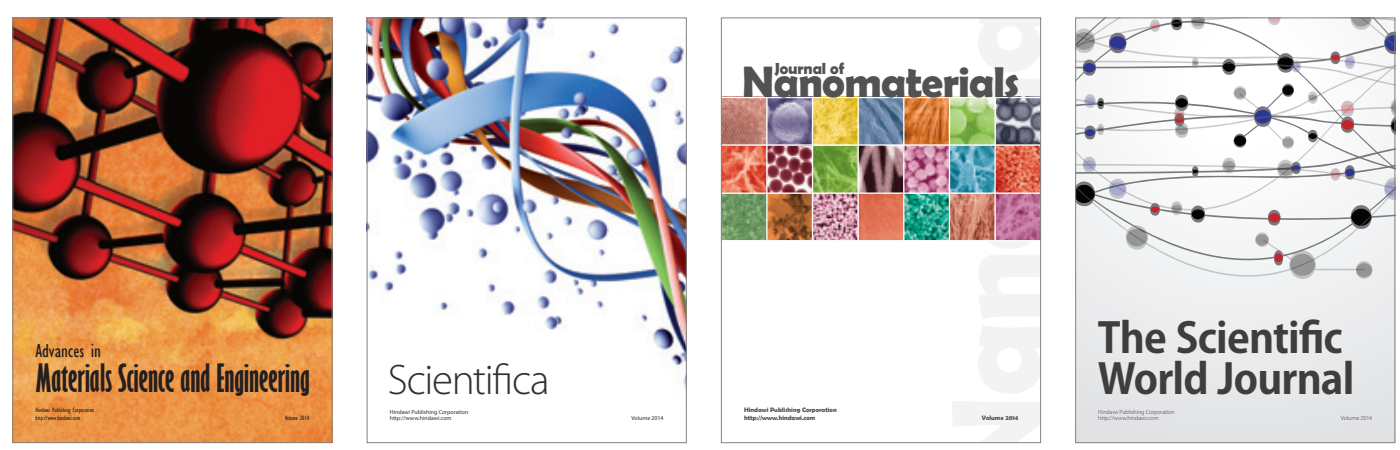

\section{The Scientific World Journal}
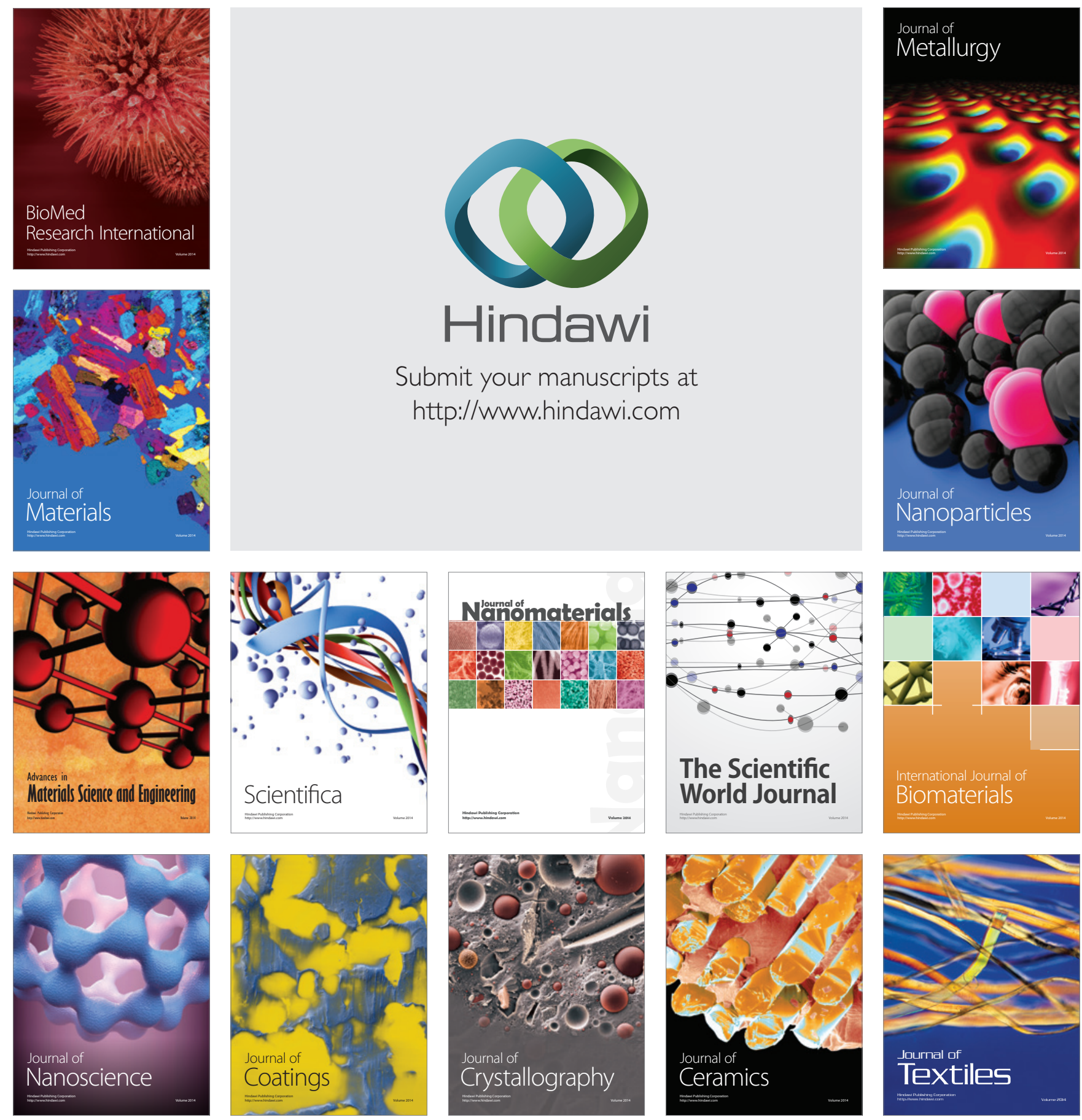